Case Report

\title{
Breast Plasty by Selective Mastectomy on Thoracic Supernumerary Breast: A Case Report
}

\author{
Noa Ndoua Claude Cyrille ${ }^{1,2, *}$, Belinga Etienne ${ }^{1,2}$, Ofakem Ilick Ingrid Doriane ${ }^{1}$, Metogo Junie ${ }^{1,2}$, \\ Kasia Onana Yves Bertrand ${ }^{2}$, Mendibi Sandrine ${ }^{2}$, Kemfang Ngowa Jean-Dupont ${ }^{1,2}$, \\ Kasia Jean Marie ${ }^{1,2}$ \\ ${ }^{1}$ Departement of Gynecology and Obstetrics Faculty of Medicine and Biomedical Science, University of Yaounde I, Yaounde, Cameroon \\ ${ }^{2}$ Gynecological Endoscopic Surgery and Human Reproductive Teaching Hospital, Yaounde, Cameroon
}

\section{Email address:}

claudenoa@yahoo.co.uk (N. N. C. Cyrille)

${ }^{*}$ Corresponding author

\section{To cite this article:}

Noa Ndoua Claude Cyrille, Belinga Etienne, Ofakem Ilick Ingrid Doriane, Metogo Junie, Kasia Onana Yves Bertrand, Mendibi Sandrine, Kemfang Ngowa Jean-Dupont, Kasia Jean Marie. Breast Plasty by Selective Mastectomy on Thoracic Supernumerary Breast: A Case Report. Journal of Gynecology and Obstetrics. Vol. 7, No. 3, 2019, pp. 68-71. doi: 10.11648/j.jgo.20190703.12

Received: October 21, 2018; Accepted: December 3, 2018; Published: May 27, 2019

\begin{abstract}
Background: Supernumerary breasts result from the persistence of ectopic mammary buds on the path of the primary mammary crest. The thoracic location with presence of glandular tissue remains exceptional. In its management, the surgeon is confronted not only with the aesthetic concern but also with the problem of surveillance given the risk of neoplastic degeneration due to the persistence of the supernumerary breast. It is then a question of determining the moment of the surgery and especially the appropriate operative technique. Presentation of the case: A 14-year-old girl was received for aesthetic gene linked to the presence of two nipples on her left breast. The physical examination revealed an asymmetry of left and right breasts volume. The left breast was classified as class I mammary glands according to KAJAVA classification. The mammogram described two mammary glands juxtaposed 180 and $80 \mathrm{~cm}^{3}$ respectively. After performing the preoperative schema, the surgical procedure consisted of a selective mastectomy by complete excision of the lower mammary gland of $80 \mathrm{~cm}^{3}$ with remodeling by sub-mammary detachment over $2 \mathrm{~cm}$ of the remaining gland. The postoperative course was simple. Conclusion: Selective mastectomy for thoracic supernumerary breast is a technique of easy realization. The surgeon must find his anatomy to properly choose the preoperative schema. The postoperative result in our case was satisfactory.
\end{abstract}

Keywords: Breastplasty, Selective Mastectomy, Supernumerary Breast

\section{Introduction}

The breast pathology of the adolescent includes breast infections, breast discharge, tumor pathology of the breast, and mammary gland abnormalities development [1]. The formation of the mammary buds begins on the 35th day of gestation. They are 10 to 20 distributed on the middle axillary line (primitive mammary crest). Most of them do not develop and only the 2 thoracic buds persist leading to the formation of the breasts which become palpable only around the 34 th week of gestation. Polymastia or supernumerary breast result in the failure of the regression of the others buds. Apart from the aesthetics concerns it may degenerate to cancer [2]. There is therefore a need for its total ablation. As concern, the surgeon has to clearly describe the anatomy of the abnormal breast using the clinical examination and the mammogram. He has to choose the best pre-operative schema for the surgery that enables the total removal of the breast and the best aesthetic result. We report a case of breast plasty by selective mastectomy on left thoracic supernumerary breast in a 14-year-old girl with satisfactory result in which we discuss surgical management.

\section{Case Presentation}

A 14-year-old girl was received in the outpatient clinic for 
the presence of two nipples on her left breast. The physical examination revealed a left and right breast volume asymmetry at the expense of the left, which moreover described two nipples, two areolas and two mammary glands defining class I according to the KAJAVA classification of supernumerary breasts Figure 1. The mammogram revealed two juxtaposed mammary glands with different volumes; 180 $\mathrm{cc}$ and $80 \mathrm{cc}$, respectively. Figure 2. She underwent a selective mastectomy by complete excision of the lower mammary gland Figure 3, 4, 5 with remodeling by prepectoral detachment over $2 \mathrm{~cm}$ of the remaining gland Figure 6 . After the surgery, both breasts was symmetrical and of substantially comparable in volume Figure 7. The postoperative course was uneventful Figure 8. The pathologic examination after surgical excision showed normal breast tissue.

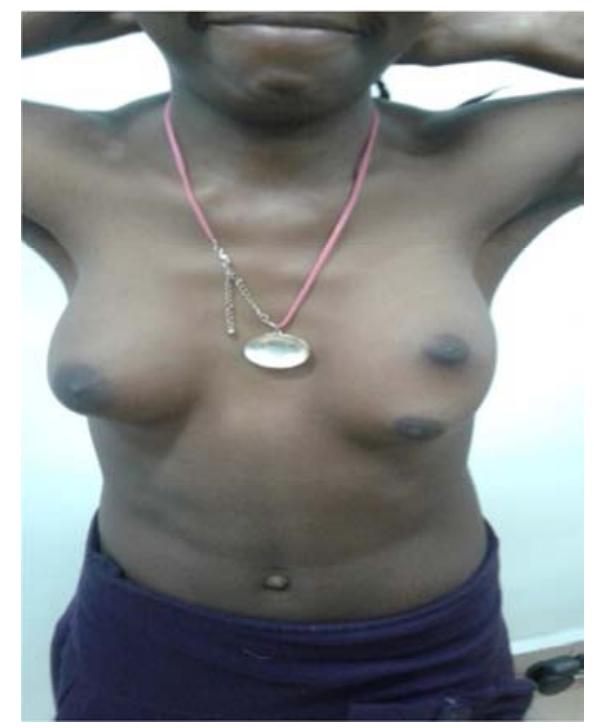

Figure 1. Clinical presentation of the breast.

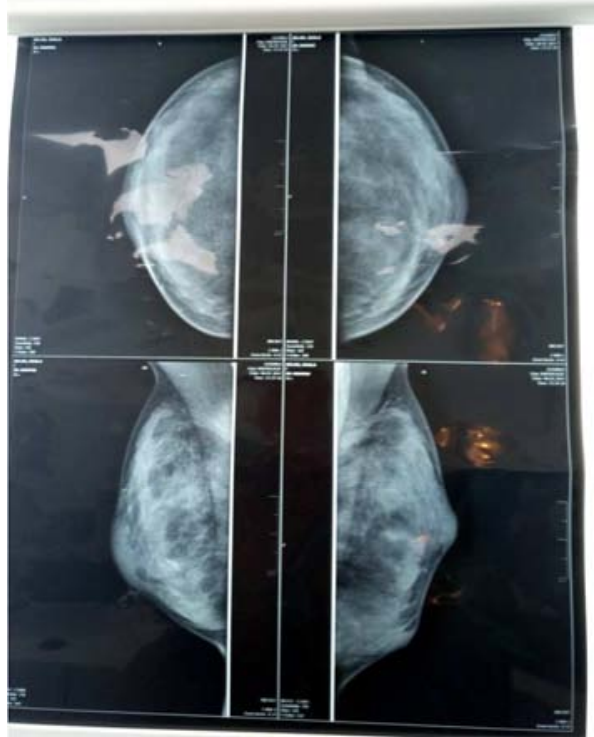

Figure 2. Mammogram.

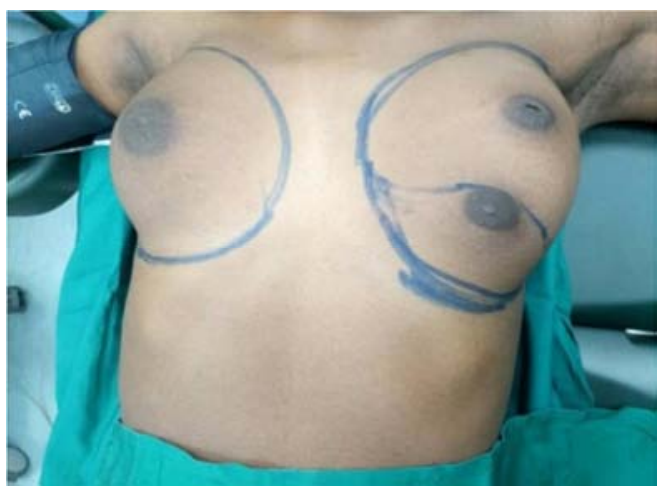

Figure 3. Preoperative view.

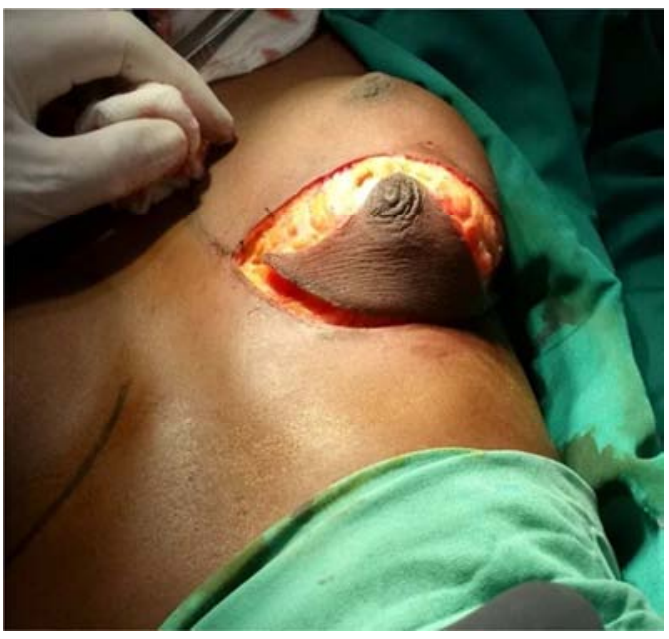

Figure 4. Cutaneous incision.

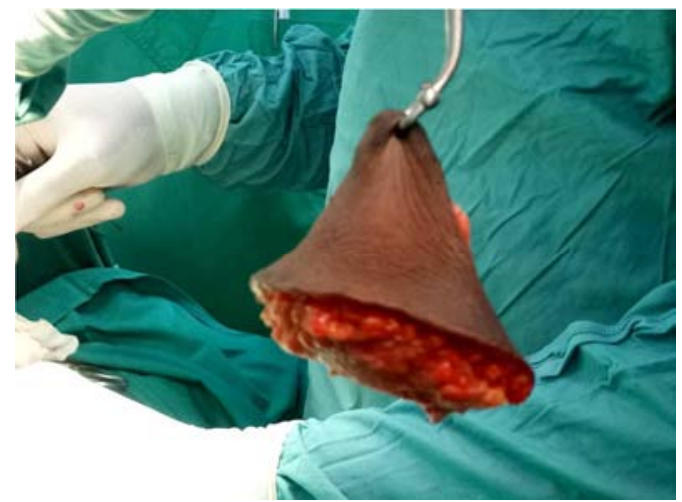

Figure 5. Ablated supernumerary breast.

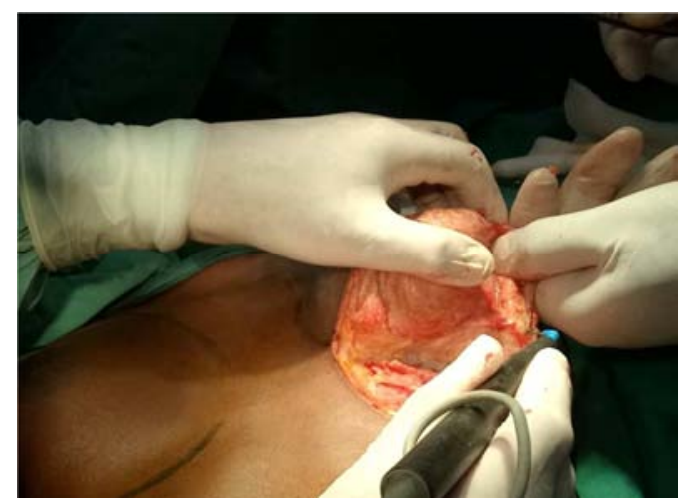

Figure 6. Remodeling. 


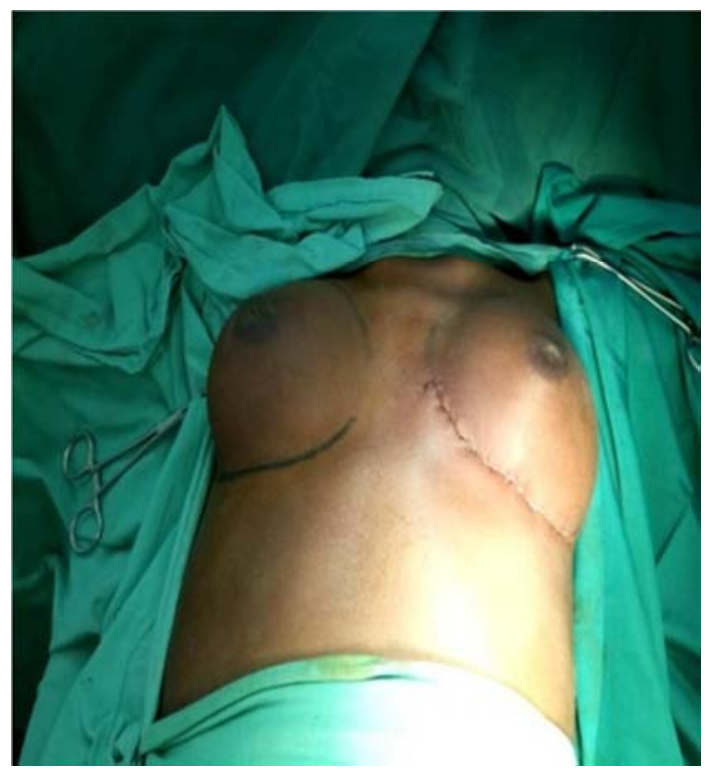

Figure 7. Immediate post-operative view.

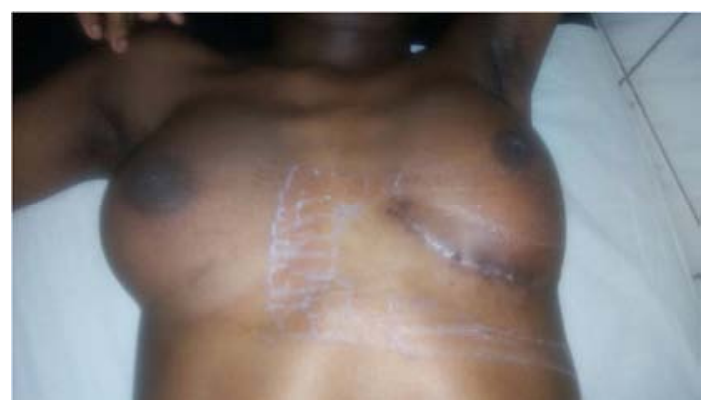

Figure 8. View 14 days postoperative.

\section{Discussion}

The incidence of supernumerary breasts in the female population ranges from 2 to $6 \%$ [3]. It is also more common in men than women. In $67 \%$ of cases, polythelia is found on the thorax or abdomen and in $20 \%$ of cases on the axillary region $[3,4]$. The complete supernumerary breast (polythelia and polymastia) as described in our case is only very rarely found in the thoracic region. The presence of two nipples, two areolas and two mammary glands thus defines class I according to the KAJAVA classification [5]. Diagnosis of supernumerary nipple or polythelia is done at birth. However, it is necessary to wait for the age of the puberty or the occurrence of a pregnancy to see the breast-feeding to make the diagnosis of polymastia [6].

The surgery depends on the importance of the aesthetic discomfort, the volume of the supernumerary breast and its location. However, Fama et al [6]. recommend early surgical management for class I to IV abnormalities because of the high risk of cancer for these classes. Similarly, surgery is often required in front of a thoracic supernumerary breast because of the aesthetic discomfort with respect to an axillary localization that is practically embedded in the axillary fat. The controversy persists as to the therapeutic attitude in case of axillary localization. Some authors advocate abstention without complications, others prefer systematic resection [7, 8]. However, surgical excision is useful to clarify the histological nature and avoid malignant degeneration risk which represents $0.3 \%$ to $0.6 \%$ of breast cancers $[3,9]$.

Some authors advocate liposuction as a therapeutic but the latter is less recommended due to the fact of the incomplete resection. According to Aydogan and Singall, it is difficult to remove fibroglandular tissue from the breast. In axillary locations liposuction gives satisfactory results because they are almost embedded in axillary fat.

The age of the surgery varies according to authors and don't obeys any consensus. According to Singall [3], the age of patients at the time of surgery ranged from 19 to 54 years with an average of 28.8 years. Some authors such as Aydogan and El Bouzidi $[4,10]$ recommend management before puberty or as soon as the diagnosis is made. However, we must take into account the delay of care due to non-compliance of parents.

With regard to the surgical technique, the two glands being arranged in stages a selective mastectomy can easily be performed using the simple technique of the under-breast sulcus described by Fitoussi [11]. for tumors close to the sub-mammary sulcus. This technique allows easy remodeling by partial separation under mammary of the remaining gland. The detached flap is left free under the cutaneous suture. Cinpolat et al [12] use the middle pedicle Wise technique with a satisfactory aesthetic result.

\section{Conclusion}

Selective mastectomy for thoracic supernumerary breast is a technique of easy realization. The surgeon must find his anatomy to properly choose the preoperative schema in order to remove the total aberrant breast and to have an interesting aesthetic result. The postoperative result in our case was satisfactory.

\section{References}

[1] Khoumane N, Yousfi M. Seins surnuméraires axillaires bilatéraux. Pan African Medical Journal. 2014; 17: 45.

[2] Guèye M., Guèye S., Rault S., Ronzino V., Gharbi M., Renard C. Cancer du sein sur la cicatrice d'exérèse d'un tissu mammaire ectopique: à propos d'un cas. Gynécologie Obstétrique \& Fertilité Volume 39, Issue 3, March 2011; 55-57.

[3] Singal R, Mehta SK, Bala J, Zaman M., Mihal A. Gupta G et al. A study of evaluation and management of rare congenital breast disease. Journal of clinical and disease research. 2016; 10 (10): $18-24$.

[4] El Bouzidi M, El Cadi M, Zoubairi I, Benabdallah K, Brahmi R, Rhrab B. Cancer bifocal du sein sur sein droit et sur sein axillaire surnuméraire homolatéral. À propos d'une observation. mt Médecine de la Reproduction, Gynécologie Endocrinologie. 2013; 15 (3): 273-8.

[5] Priti P. Patel, Ahmed M. S. Ibrahim, Jacob Zhang, John T. Nguyen, Samuel J. Lin, Bernard T. Lee, Accessory Breast Tissue. Eplasty. 2012; 12: ic5. 
[6] Shreshta S. Supernumerary Breast on the back: a case report. Indian J Surg. 2016; 78 (2): 155-57.

[7] Fama F, Cicciu M, Sindoni A, Scarfo P, Pollicino A, Giacobbe $\mathrm{G}$ et al. Prevalence of ectopic breast tissue and tumor: A 20 year single center experience. Clin Breast Cancer. 2016; 16 (4): 107-12.

[8] Baruchin A. M., Rosenberg L. Axillary breast tissue: clinical presentation and surgical treatement. Ann. Plast. Surg. 1996; 36 (6): 661-662.

[9] Lesavoy M. A., Gomez-Garcia A., Nedl R., Yospur G., Syiau T. J., Chang. Axillary breast tissue: clinical presentation and surgical treatement. Ann. Plast. Surg. 1995; 35 (4): 356-360.
[10] Aydogan F, Baghaki S, Celik V, Kocael A, Fahri G, Cetinkale O. Surgical treatment of axillary accessory breasts. The American Surgeon. 2010; 76: 270-72.

[11] Fitoussi A, Couturaud B, Delay E, Lantieri L. Chirurgie du cancer $\mathrm{du}$ sein: traitement conservateur, oncoplastie et reconstruction. Elsevier Masson. 2011. p77.

[12] Cinpolat A, Bektas G, Seyhan T, Ozad U, Coskunfirat OK. Treatment of a supernumerary large breast with medial pedicle reduction mammaplasty. Aesthetic Plast Surg. 2013 Aug; 37 (4): 762-6. 